\section{Glia for fast motor control}

The brain's glial cells once thought merely to support neurons - are increasingly regarded as having an active role in neuronal communication. Now researchers show that receptors on a specific group of glial cells are required for the coordination of fine movements in mice.

Frank Kirchhoff at the University of Saarland in Homburg, Germany, Chris De Zeeuw at Erasmus Medical Centre in Rotterdam in the Netherlands and their colleagues deleted a type of neurotransmitter receptor called AMPA from Bergmann glial cells in mice. As a result, the appendages of these cells shrank back from certain synapses - the connections between neurons - and synapse formation was delayed. Three months after the AMPA-receptor deletion, the mice stumbled and took more missteps in a motor performance test than did control animals, and also showed deficits in motor learning.

AMPA receptors on Bergmann glial cells help to fine-tune neuronal activity, the researchers suggest.

Science http://dx.doi. org/10.1126/science. 1221140 (2012) \section{MATERIALS}

\section{Fluorine makes graphene stickier}

Coating materials with fluorine typically decreases friction on the surface, as in the non-stick coating Teflon. However, on graphene - an atomically thin sheet of carbon atoms - the fluorine coating has the opposite effect.

Yong-Hyun Kim and Jeong Young Park at the Korea Advanced Institute of Science and Technology in Daejeon, South Korea, and their colleagues found that the tiny tip of an atomic force microscope slides more easily over graphene than it does over the same sheet coated with fluorine atoms. Fluorinated graphene is stiffer than bare graphene and this lower flexibility may obstruct the tip, causing more friction. This could also explain why friction increases in both hydrogenated graphene and in graphene oxide - although another possibility is that adding fluorine, hydrogen or oxygen atoms to graphene gives a more disordered, corrugated structure. The findings could help those building nanometre-scale devices to avoid excess friction.

Nano Lett. http://dx.doi. org/10.1021/nl204019k (2012)

$$
\text { MICROBIOLOGY }
$$

\section{Bacteria bore through biofilms}

Some bacterial species form tough layers on surfaces, known as biofilms, as a means of self-protection. However, swimming subpopulations of a few bacterial species can penetrate biofilms, making them vulnerable to destruction.

Romain Briandet and his colleagues at the Micalis Institute in Jouy-en-Josas, France, report that a tiny proportion of certain Bacillus species can tunnel through biofilms, creating pores that allow molecules to flow in. Exposing Staphylococcus aureus biofilms - a common problem in hospitals and industrial settings - to bacilli swimmers and to an antimicrobial called benzalkonium chloride killed approximately 300 times more $S$. aureus than treatment with the antimicrobial alone.

Supplementing antimicrobial treatments with swimming bacilli could increase their efficacy, the researchers suggest.

Proc. Natl Acad. Sci. USA http://dx.doi.org/10.1073/ pnas.1200791109 (2012)

COMMUNITY CHOICE

The most viewed papers in science

\title{
Why Antarctica is melting
}

\section{a highly read \\ on www.agu.org the week of 25 June}

Melting at the base of Antarctica's Fimbul Ice Shelf is driven by warm surface water, as well as intermittent pulses of warmer, deeper water.

Tore Hattermann of the Norwegian Polar Institute in Tromsø and his co-workers collected temperature data in 2010 and 2011 from three moorings installed below the Fimbul shelf. Their data suggest that the shelf is affected by surface waters warmed by solar radiation and by freshwater run-off from seaice melt during the late summer and autumn. Eddies also bring warm water from the depths to underneath the ice shelf, often in pulses lasting less than 10 hours.

Although previous studies have pinpointed temperature changes in deep water as mediating the increased ice melting due to climate change, the findings paint a more complex picture of melting at the Fimbul ice shelf.

Geophys. Res. Lett. http://dx.doi.org/10.1029/2012GL051012 (2012)

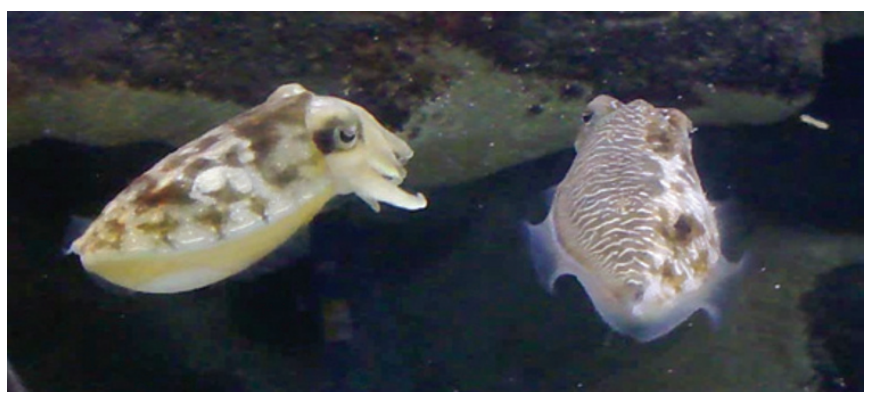

\section{ANIMAL BEHAVIOUR}

\section{Two-faced cuttlefish}

Taking advantage of their ability to change colour, male mourning cuttlefish display courtship markings to a female with one side of their bodies, while displaying female markings to a male on the other side to avoid being perceived as a rival.

Culum Brown and his colleagues at Macquarie University in Sydney, Australia, studied photographs of 138 male mourning cuttlefish (Sepia plangon) in the company of females in Sydney Harbour and observed animals grouped in an aquarium. The researchers found that when a male (pictured right) was courting a single female (left) in the company of another male, the courting male would display the half-and-half deception in $39 \%$ of cases.

Complete female mimicry has been observed in other species, as has the use of a different pattern on each side of the body to deceive predators. However, this is the first time that an animal has been seen to use laterally split markings for gender deception.

Biol. Lett. http://dx.doi. org/10.1098/rsbl.2012.0435 (2012)

For a video of the cuttlefish, see go.nature.com/zothlh

\section{$\rightarrow$ NATURE.COM}

For the latest research published by Naturevisit:

www.nature,com/latestresearch 